\title{
NOTES ON SOME ALEYRODES FROM MASSACHUSETTS, WITH DESCRIPTIONS OF NEW SPECIES.
}

\author{
BY AUSTIN W. MORRILl, B. SC., MASSACHUSETtS AGRICUltURAL COLlEGe, \\ AMHERST, MASS.
}

In his Contributions toward a monograph of the American Aleurodidae (U. S. dept. agric. Div. ent. Bull. Tech. ser. 8, I900), Quaintance reports only one species of the genus Aleyrodes (=Aleurodes of some writers) as occurring in Massachusetts or even in New England, and this, the greenhouse Aleyrodes (A. vaporariorum), is probably not a native species. As a whole the genus appears to be most typical of the warmer climates, a large proportion of the described North American species being found in Georgia, Florida, California, and Mexico.

In New England except for the greenhouse ( $A$. vaporariorum) and the strawberry ( $A$. packardi) Aleyrodes, conditions do not seem favorable for their occurrence in large numbers. It is probable that the difficulty with which most species of Aleyrodes live through severe winters explains their comparative scarcity. In regard to the manner in which Aleyrodes pass the winters, Signoret in his Essai monographique sur les Aleurodes (Ann. soc. ent. France, r 868) says: "A n'importe quel état on les voit passer l'hiver : à l'état parfait dans les anfractuosités des arbres et des terres et même sous les feuilles; à l'état d'oeufs de larves ou de nymphes, sous les feuilles tombées, sous les feuilles de plantes qui les conservent, telles que le fraisier, le chélidoine, l'alaterne et les choux."

My own observations would indicate that adult ALEYRODES do not hibernate in this climate, although they are certainly able to stand a great amount of cold. The following extract from my notes on the strawberry Aleyrodes illustrates this last statement: "Nov. Ir. A heavy frost last night as well as several preceding nights ; adults on strawberry leaves appeared benumbed but became active again soon after being brought into a warm room."

The eggs of this species ( $A$. packardi) deposited by.the adults on the under surface of the leaves in the fall of rgor, began to hatch the following spring as early as March 23. From this time till April I 4 many eggs hatched, but apparently all these larvae were killed by the frosts. Of the larvae that hatched later than April r4, few if any succumbed to the cold. The adults began to emerge from the pupa cases about the twentieth of May, previous to which time none were seen although a thorough search was made nearly every day. If the adults hibernated it is almost certain that they would have made their appearance before so late in the season. 
These observations lead to the conclusion that, for this species at least, our winters are so cold as to destroy all stages except the egg. If those species whose food plants are deciduous also pass the winter in the egg stage, it would seem necessary, from our knowledge of the habits of the young larvae of Alevrrodes that the eggs be laid on or near the leaf buds, and even then the larvae would have but a slight chance of reaching maturity.

On the other hand the multiplication of Aleyrodes seems to be favored by parthenogenesis. I have thus far discovered this method of reproduction only in A. vaporariorum, but it probably occurs in many if not all other species of the genus. Correlated with this, I have found female ALEyrodes to be much more abundant than the males. Out of eighty-five adults taken at random, representing four different species, I found but twenty males to sixty-five females, and these figures probably represent about the usual proportion of the sexes in nature.

In regard to the length of life of the adult, and the number of eggs laid by each female, I can only state that in one instance a female of $A$. vaporariorum lived in the adult condition twenty-five days, and laid a few more than forty-five eggs.

I have here briefly considered only a few of the biological problems connected with this interesting group of insects. Very few observations have thus far been made in this direction and until the appearance of Quaintance's admirable paper, the group was much neglected systematically. During the summer of 1902 at Amherst, Mass., I found the five species of Aleyrodes mentioned below, but others - both known and unknown - undoubtedly occur in this region. It is the hope of the writer that this paper may lead to the recording of such by other workers in entomology.

I. Aleyrodes mori maculata, subsp. nov.

PUPA CASE. Shiny black, elliptical; length, .72-.76 mm., width, .48-.54 mm. A copious white cottony fringe all around, continuous proximally, but ragged distally. "On dorsum of both mesothorax and metathorax near dorsi-meson is a pair of small brown setae; also a pair of setae near vasiform orifice and on caudal margin of case... There is a pair of minute setae on the margin of case, one on each side near caudo-lateral region. On fourth abdominal segment on each side there is a group of from four to six minute pores. One or two pores are sometimes present on fifth segment on each side, just caudad of those on fourth."-Quaintance (A. mori).

Adult. Fore wings marked with red and brownish black. Body with conspicuous blackish markings as follows: a transverse band across front of head, between bases of antennae; a more or less distinct dark spot on each side just above the eye; a roundish black spot on each side of prothorax just below the dorsum; a more or less elliptical black spot covering a nearly equal area on each side of mesothorax, in front of and below the insertion of fore wings, - these last two pairs of spots together occupying a space on each side of the body about equal in size to one of the dumb-bell shaped compound eyes; an elongated spot on dorsum of mesothorax on each side in front of insertion of fore wing - these spots are 
oblique converging posteriorly; a smaller spot on each side of dorsum of metathorax posteriorly; a transverse spot on dorsum of abdomen just anterior to variform orifice; and a border along the posterior margin of the operculum. In addition to these clearly defined markings, there may be slight tinges of black elsewhere, seen soon after emergence from pupa case but later hidden by the flour-like wax secretion. When mounted in balsam the thorax appears of a deep orange yellow color with brownish markings, and the abdomen pale yellow in color with brownish markings.

In the Can. ent. vol. $3 \mathrm{I}, \mathrm{p} . \mathrm{I}-4$, Professor Quaintance described $A$. mori from Tampa, Fla., on mulberry, and from Lake City, Fla., on Tilia americana, Callicarpa americana, Liquidamber styraciflua, Ilex opaca and less frequently on Persia carolinensis. The pupae and adults of $A$. mori maculata agree with Professor Quaintance's description of $A$. mori except for the color of the bodies of the adults which in the latter is bright yellow. Hundreds of adults of the former have been bred and the blackish markings described above have been found to be constant.

This subspecies seems to have a wide range of food plants and to be generally distributed in this vicinity. It has been found on Cornus florida, C. sanguineus, ash, birch, and mulberry, but was not found on Tilia americana or Liquidamber styracifua although these trees grew in the neighborhood of the species of Cornus upon whose leaves this insect was quite abundant. Cornus seems to be the favorite food plant, although even on that plant rarely more than one half dozen pupae are found on a single leaf.

Types of pupae and adults have been deposited at the Massachusetts agricultural college.

2. Aleyrodes forbesil Ashmead.

A. aceris Forbes, I 4 th rept. Ill. state ent., p. I 10. (1884.)

$A$. forbesii Ashmead, Bull. 45 U. S. nat. mus., p. 294. (1893.)

A. forbesii Quaintance, U. S. dept. agric. Div. ent. Bull. Tech. ser. 8, p. I5, 27. (1900.)

A single specimen of the pupa of this species was found on maple, Acer dasycarpum, and a few very large adult Aleyrodes which I took to be of this species were seen on near-by leaves.

3. Aleyrodes vaporariorum Westw.

Gardener's Chronicle, r856, p. $85_{2}^{2}$. Signoret, Ann. soc. ent. France, Dec. r868, p. 387. Quaintance, U. S. dept. agric. Div. ent. Bull. Tech. ser. 8, p. r6, 39 (r900). Britton, Bull. r40 Conn. exp. station (r902). Morrill, Can. ent. vol. 35, p. $25,26(1903)$.

This species is found rarely out of doors in this locality. It was observed last summer on butternut, nasturtiums, maple, tomato, and tobacco. It has a wide range of food plants in the green house, more than fifty being recorded by Britton. 


\section{Aleyrodes packardi Morrill.}

Can. ent., vol. 35 , p. 25-35. (I903.)

This species is very abundant on strawberries at Amherst and appears to be generally distributed throughout the Eastern United States. I have found it occasionally on Camperdowm elm, Spiraea, and ash.

\section{Aleyrodes fernaldi, sp. nov.}

FULL GROWN LARVA. Length, $.52 \mathrm{~mm}$., greatest width, $30 \mathrm{~mm}$. Form broadly elliptical. Color pale yellowish green with an irregular orange yellow body on each side in the basal abdominal region. Abdominal segmentation distinct, thoracic segmentation less so. Margin crenulated, surrounded by a narrow fringe of wax. Three pairs of marginal spines : one pair on cephalic margin, very minute; one pair on caudo-lateral region, one on each side, very minute; a pair on caudal margin, about one tenth the length of the body. Vasiform orifice essentially as in pupa. Eyes small, color dark red. In the single specimen examined but one pair of dorsal spines was observed. These were on the cephalic region between the eyes.

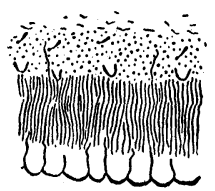

Aleyrodes fernaldi. Portion of margin of pupa.

Pupa. Length, .72-.84 mm., greatest width, $.44^{-.54} \mathrm{~mm}$. Form, subelliptical, slightly narrowed anteriorly; dorsal surface nearly flat; older specimens raised from surface of leaf by vertical wax fringe; margin fully crenulated. Color when freshly moulted, pale greenish white, operculum tinged with yellowish; older specimens except for a space of about one fourth the width of the body all around the margin covered with a white, thin, amorphous waxy secretion, giving to the pupae on a leaf a clear white appearance. Space between extreme margin and part covered by wax showing fine radiating striae and glistening structures which appear like rounded or conical protuberances. Across the middle of the dorsum, breaks in the waxy covering indicate the divisions between the body segments and in addition a median longitudinal break extends along the dorsum from the

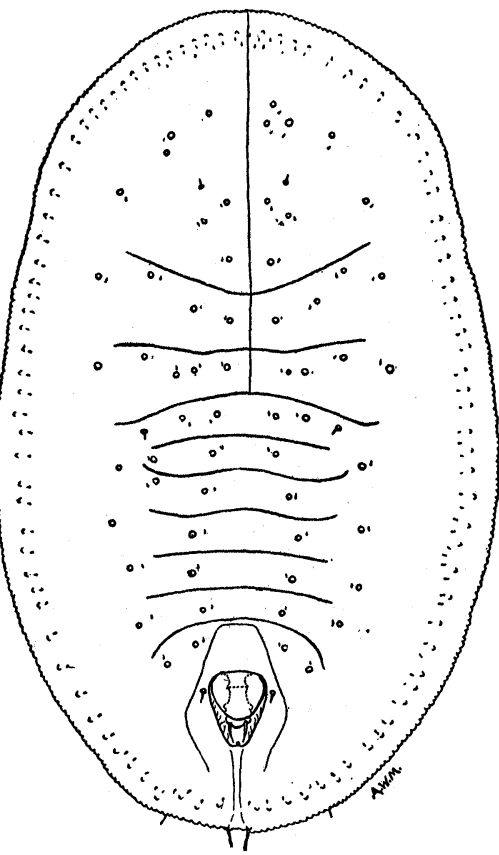

Aleyrodes fernaldi. Dorsum of pupa. anterior edge of body to the base of abdomen. Wax covering or plate otherwise interrupted by rather large irregular openings through which circular pores in integument can be frequently seen, $-i$. e. one to each opening. 
By dropping the pupa into xylol for a few minutes to clear and dissolve off the wax, and then mounting in xylol balsam, the surface structures can be plainly seen.

A pair of short caudal setae arise from minute papillae, barely within the caudal margin. A still smaller pair arise one on each side, a short distance from the first pair on caudolateral margin. Vasiform orifice subovate, one fourth longer than broad, indented posteriorly. Corrugations or folds extend downward and inward from sides of orifice. Operculum very broadly ovate, extending a little more than one half the distance toward caudal end of orifice. Lingula spatulate, setose, bearing distally three distinct side lobes on each side and a single terminal lobe. All except terminal lobe and posterior pair of side lobes covered by operculum. From each side of terminal lobe a rather stout seta arises extending caudad nearly to apex of orifice. On cephalic region about one fifth of distance from cephalic to caudal margin is a pair of spines, one on each side of middle; on first abdominal segment a second pair, one on each side; and near vasiform orifice, opposite the widest part, a third pair of spines, one on each side. These three pairs of spines are all simple, minute, and of about equal size. Extreme margin irregularly radiately striated. A short distance mesad from margin is a row, all around, of small conical projections or thickenings and mesad to these, a row of minute knobbed setae. The structures of the inner row as a rule correspond in number and position to those of the outer row. Mesad to these two rows, body loses its striated appearance and is somewhat rugose. On each side of middle of dorsum are the circular pores already mentioned. As a rule these never occur nearer the margin than a distance equal to one fifth. width of body. There are about twenty-seven pairs of these, and almost invariably several unpaired ones also occur, particularly on cephalic region. Near each pore is a minute knobbed seta similar to those near margin of body. There are about fifteen or sixteen pores on cephalic region, those most anterior being usually unpaired; there are usually four pairs on mesothoracic region, four pairs on metathoracic region, two pairs on first abdominal segment, one pair on second, and two pairs each on the five following segments. On the under side of body the short and stout legs and antennae can be plainly seen. Antenuae lie in pockets outside of first pair of legs, are stout, near the outer end abruptly narrowed, forming a slender tip.

Adult $q$. Length I.-I.2 mm. Color, pale yellow, becoming covered with white flourlike substance a short time after emerging from pupa case. Rostrum usually tipped with black. Wings immaculate, about I.I $\mathrm{mm}$. long, and .48 $\mathrm{mm}$. broad, with a single unbranched median vein; on margin are globular beads which bear on outer side several minute setae. Eyes divided into two parts; color, dark red. Legs and antennae of specimens mounted in xylol balsam nearly colorless. Segments of antennae show following proportions with eyepiece-micrometer, one-inch eyepiece, and one-half-inch obj. : 2-5-II-3$4 \frac{1}{2}-4-3 \frac{1}{2}$.

Adult $\delta$. Length $.9 \mathrm{~mm}$. Proportionally smaller than $q$, otherwise differing only in sexual organs.

This is a common species in this locality (Amherst, Mass.), occurring abundantly on several species of Spiraea. I have also found it though less frequently on strawberry with Aleyrodes packardi.

I take pleasure in naming this insect for Prof. C. H. Fernald who first called my attention to its occurrence on Spiraea growing on the college grounds. 
Described from a single specimen of the larva, numerous specimens of the pupae and adult females, and a single specimen of the adult male. Types have been deposited in the collection of the Massachusetts agricultural college.

A hymenopterous parasite which I bred from a pupa of this species was determined by Mr. W. H. Ashmead, of the U. S. national museum, as a male of an Encarsia, without much doubt the male of Encarsia luteola Howard; but as luteola was described from a female it was impossible to give the specific determination positively.

THE HEMIPTERA DESCRIBED BY PHILIP REESE UHLER. II. BY SAMUEL HENSHAW, CAMBRIDGE, MASS.

CAPSIDAE.

Diaphnidia, 46-43

debilis, 46-43 Col.: Steamboat Springs.

pellucida, 46-44. Col.: Ft. Collins ; [Can.]: Quebec, near Montmorency;

D. C. : near Washington.

\section{Dicyphus}

lautus, 47-267 Japan.

minimus, 50-59 Fla.

separatus, 43-r94 Mass. : Camb.; to Fla. and Tex.; Cal.; Grenada.

vestitus, 46-46 Col.: Fort Collins, Montrose; [Cal.]: Los Angeles ;

Dak.; N. N. Y.

Diommatus, 26-32

angulatus, 46-44 Col.: Ft. Collins, Montrose.

congrex, 26-33 E. Mass. ; Me.; Can.; Ill.; N. Y.: Lancaster.

ECCRITOTARSUS

elegans, 28-r49 C. Tex.; Kans.: Riley Co.; Ill.; Cal.: Los Angeles.

scabrosus, 46-40 Col.: Estes Park.

ECTOPIOCERUS, 33-73

anthracinus, 33-74 Cal.: Santa Clara, near San Francisco.

EUCEROCORIS

guttulatus, 28-I50 Md.: E. shore Chesapeake bay to hills of Frederick

\section{Fulvius}

Co. ; Tex.; W. Ill.

lunulatus, 43-192 Grenada. 

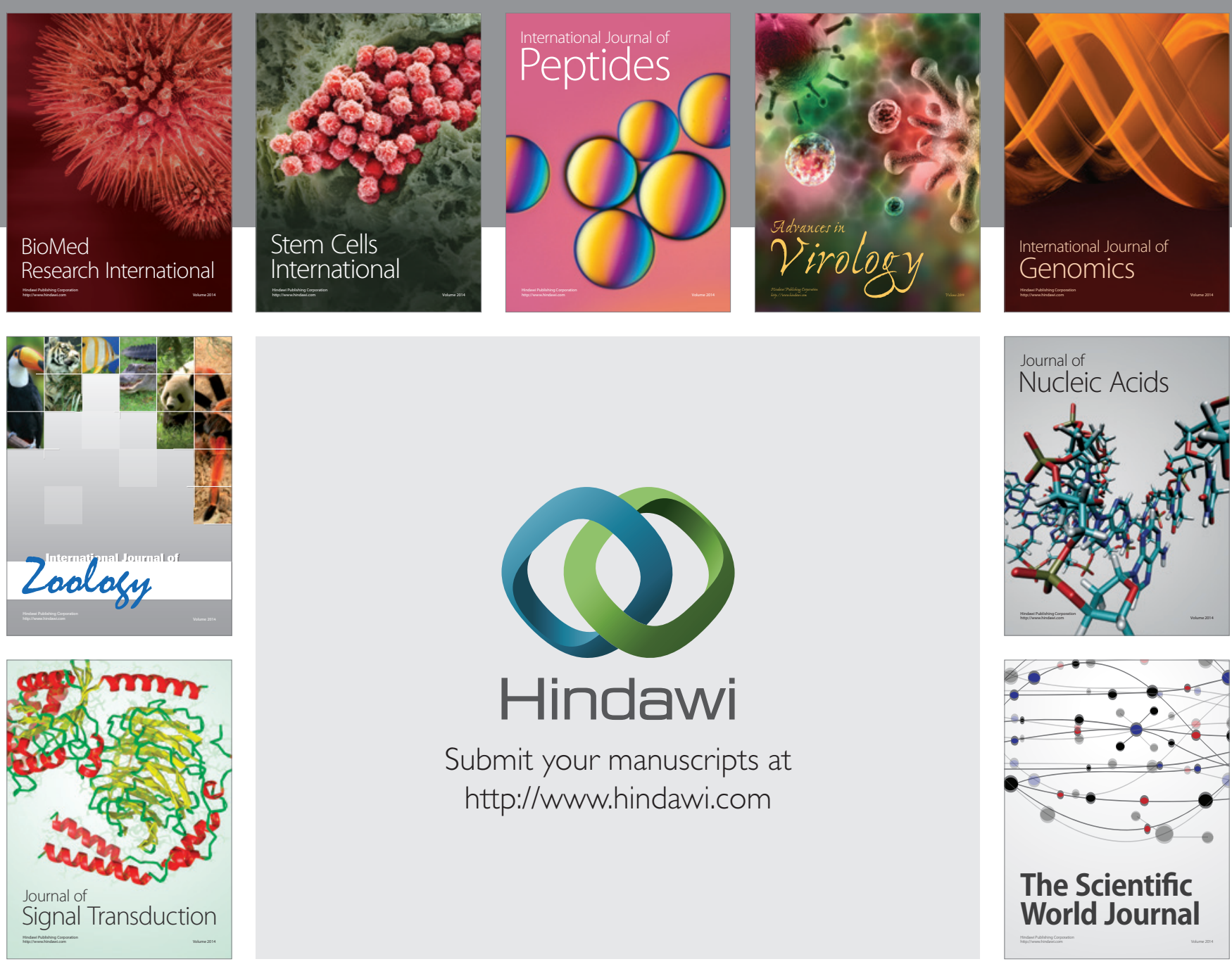

Submit your manuscripts at

http://www.hindawi.com
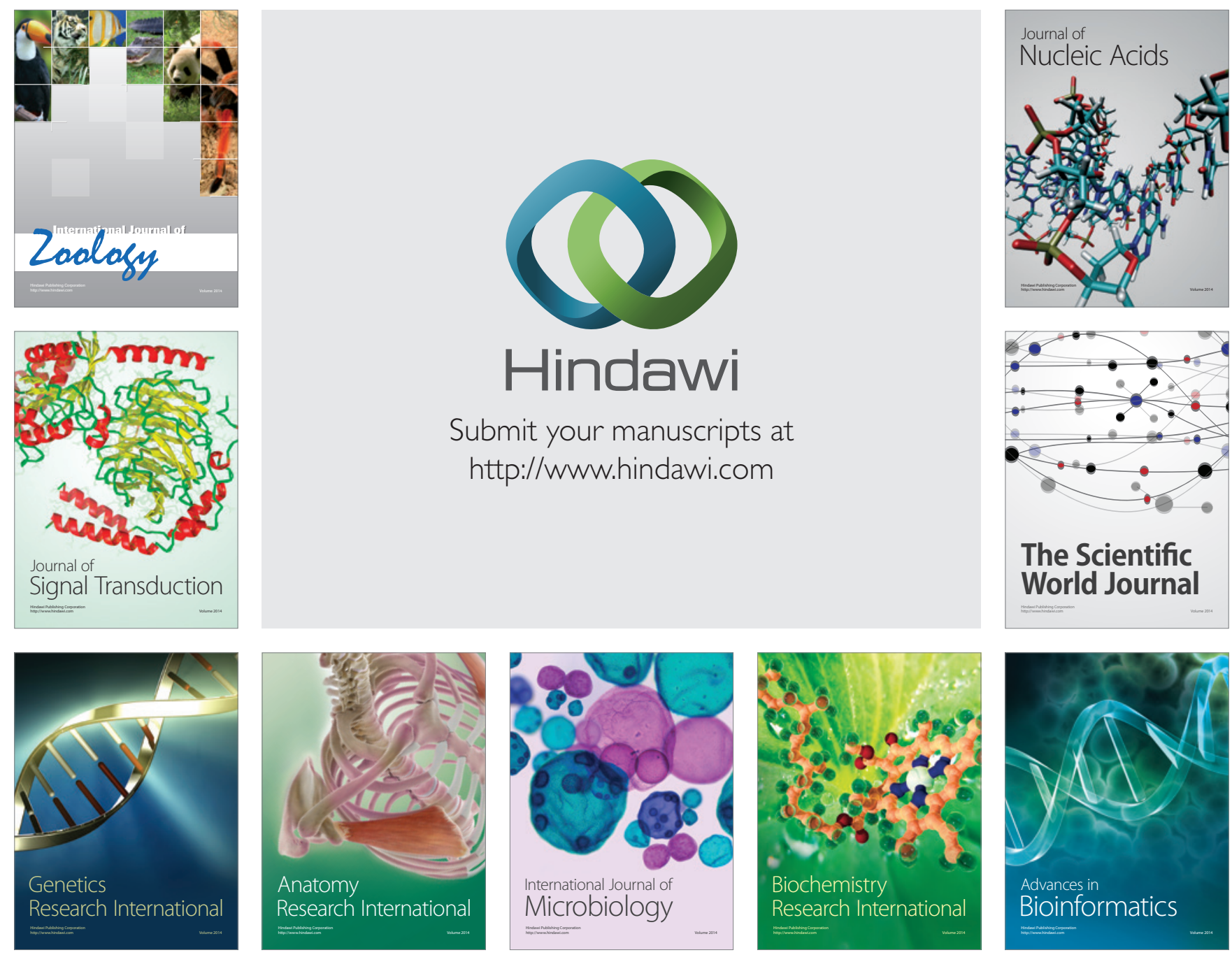

The Scientific World Journal
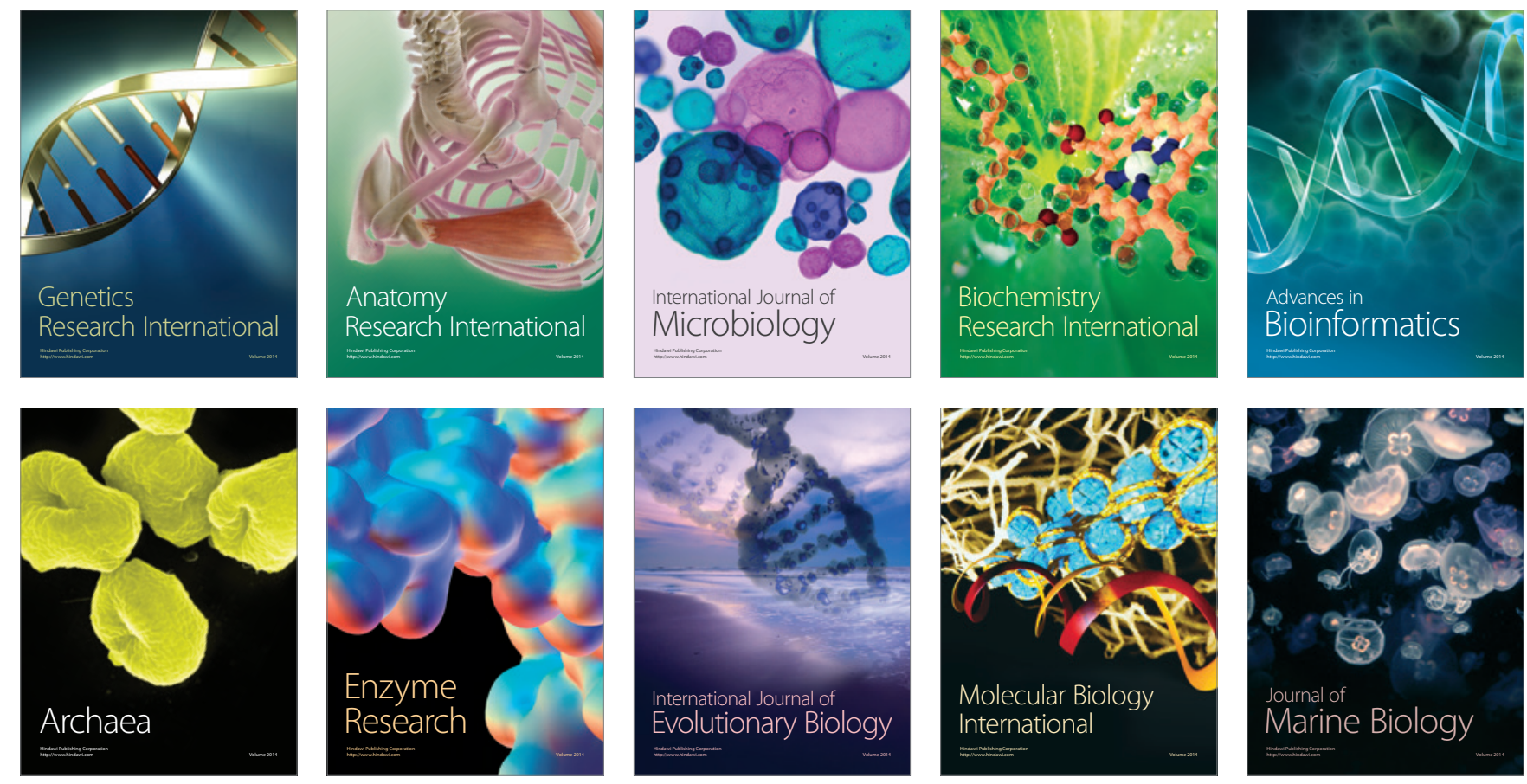